This is the author's final, peer-reviewed manuscript as accepted for publication. The publisher-formatted version may be available through the publisher's web site or your institution's library.

\title{
Narrative Inquiry Invites Professional Development: Educators Claim the Creative Space of Praxis
}

Margaret Macintyre Latta, University of Nebraska, Lincoln

mlatta2@unl.edu

Jeong-Hee Kim, Kansas State University

jhkim@ksu.edu

\section{How to cite this manuscript (APA format)}

If you make reference to this version of the manuscript, use the following citation format:

Latta, M.M., Kim, J.H. (2009). Narrative Inquiry Invites Professional Development:

Educators Claim the Creative Space of Praxis. Retrieved from http://krex.ksu.edu

\section{Published Version Information}

Citation: Latta, M.M. \& Kim, J.H. (2009). Narrative inquiry invites professional development: Educators claim the creative space of praxis. The Journal of Educational Research, 103 (2), 137-148.

Copyright: Copyright (c) Taylor \& Francis Group

Digital Object Identifier (DOI): DOI: 10.1080/00220670903333114

Publisher's Link: http://www.informaworld.com/openurl?genre=article\&issn=00220671 \& volume $=103 \&$ issue $=2 \&$ spage $=137$

This item was retrieved from the K-State Research Exchange (K-REx), the institutional repository of Kansas State University. K-REx is available at http://krex.ksu.edu 
Running Head: NI invites Professional Development

Narrative Inquiry Invites Professional Development:

Educators Claim the Creative Space of Praxis

Margaret Macintyre Latta, University of Nebraska, Lincoln mlatta2@unl.edu

$\&$

Jeong-Hee Kim, Kansas State University

jhkim@ksu.edu 


\begin{abstract}
The current educational context, particularly with the passage of the No Child Left Behind Act of 2001, calls for evidence-based measurable student learning outcomes. Increasingly, teachers feel that opportunities for their praxis are closed off to create, adapt, and discern within the act of teaching, leaving them with little felt agency in classrooms. In this paper, we explore how narrative inquiry used as a medium for professional development can create a needed space where teacher agency for praxis is fostered individually and collectively through understanding otherness. We conclude narrative inquiry invites participating educators to claim the creative space of praxis in their classrooms and fosters a culture of professional learning across participants that we see as the formative work necessary within professional development.
\end{abstract}




\section{Introduction}

The positivist epistemology of practice (Schön, 1983) is ubiquitous within all aspects of education, confining many professional development initiatives to mandates insisting on evidence-based practices intended to enhance student achievement. These initiatives are to be carried out by teachers, but most often, are under-resourced, mis-communicated, and entail little teacher input and/or knowledge about the particular reasoning, approaches or intents. The research literature reiterates these concerns and documents the ensuing consequences (e.g., M Cochran-Smith \& Lytle, 2001; Darling-Hammond, 1996; Day, 2000; Delpit, 2000; Fullan, 1999; Hansen, 2001; Hargreaves, 2002; Nias, 1996; Noddings, 1996; Richardson, 2003). Teachers are provided with teacher-proof curricular materials as if they are incapable of making educational decisions, and they are asked to provide measurable, quantifiable, certain, scientific results that fit fixed ends. Thus, teaching practices are tailored to essential priorities that ensure predetermined economic, political and ideological agendas. And, the outcomes of such evidencebased teaching practices are assured by a common method whose implementation can be monitored systematically (Dunne, 2005). In such compliant contexts praxis is, indeed, endangered (Kemmis \& Smith, 2008), preventing teachers from exercising judgments deemed wise and fitting for the particularities of teaching/learning situations while leading to a devaluation of human beings and depersonalization of our teaching practices (Kincheloe, Slattery, \& Steinberg, 2000). Thus, the cost of losing praxis is enormous. What is at stake is the loss of moral agency of the educator at the heart of educational praxis, positioning educators to become no more than the operative part of the system they work in (Kemmis \& Smith, 2008). Praxis requires educators to think outside or beyond the rules and regulations; it demands creative thinking, care, moral judgment, compassion, critical consciousness, and agency 
(Kemmis \& Smith, 2008). However, opportunities for praxis are increasingly closed off to create, adapt, and discern within the act of teaching, leaving teachers with little felt agency in classrooms. In our work as teacher educators we see teachers grappling with the denial of teaching space for such praxis in their classrooms. We observe that a detached teaching identity takes over that teachers do not necessarily feel at ease with, but it becomes a survival mode entrapping teachers. Professional action becomes a disembodied operating mode as federal, state, and district policies are mandated, fostering a culture of professional compliance instead of a culture of professional learning (Lieberman \& Pointer-Mace, 2008, p. 226).

We argue that denial of room to see and act within teaching opportunities for praxis closes off educator possibilities of seeing and acting on the potential of other(s). We also argue (among others) that creating, adapting, and discerning are fundamental to the nature of human beings and that the costs for teachers and learners of thwarting these agentic ways of being and acting in classrooms are vastly underestimated. Therefore, praxis needs to be developed and nurtured among educators through professional development. Opportunities for praxis must be created where educators can encounter, negotiate, and articulate the complexities of classrooms alongside the input of other educators. In so doing, educators can live the language of praxis, valued as productive for everyone's professional growth.

The purpose of our paper is, then, is to explore ways in which teacher learning opportunities are created and developed in order to enable teachers' praxis. Further, this paper draws attention to narrative inquiry as a medium of professional development for teacher learning and growth. Our research finds that narrative inquiry employed as a pedagogical medium in our graduate classrooms invites teachers to claim their praxis with significant implications for professional development and teacher learning. Narrative inquiry serves to foster 
meaningful professional development, reorienting teacher learning toward purposefully engaging educators in theorizing their practices in study, and concomitantly, as lived in classrooms. We document how narrative inquiry can create a needed space where teacher agency for praxis is explored and fostered individually and collectively. We find narrative inquiry invites participating educators to claim the creative space of praxis in their classrooms and fosters a culture of professional learning across participants that we see as the formative work necessary within professional development.

\section{Reframing Professional Development}

As schools face challenges to meet increasingly complex and divergent needs, teacher professional learning for teaching improvement is identified as one solution. The current challenges include students dropping out of school as early as seventh grade, and as few as $70 \%$ of U.S. students graduating from high school with the graduation rate even lower for youths of color (Barton, 2006). Furthermore, the emphasis on teacher quality enhancement as a critical component mandated by the No Child Left Behind (NCLB) of 2001 has called for compulsory teacher professional development initiatives. The lack of highly qualified teachers defined by NCLB still persists as $30 \%$ of the nation's teachers are still not meeting the law's definition of highly qualified (Trachtman, 2007). The quality gap between low and high-income schools continues to grow in a number of states even though NCLB legislation is aimed at ameliorating the chronic failure of public schools to provide experienced and highly qualified teachers for low-SES and low-achieving students. NCLB still fails to offer any mechanisms for systematically supporting and evaluating effective teachers (Trachtman, 2007). In the mean time, approximately $46 \%$ of teachers leave the profession within 5 years (Ingersoll, 2002). 
In response to increasing societal challenges, school districts mandate professional development opportunities. They offer workshops to teachers focusing on how-to's and possible quick fixes. Biesta (2007) discusses how the solution to these and similar challenges from many countries worldwide is evidence-based practice. What such evidence should look like is predetermined with learning assumptions already in place as to what is valued and why. Evidence-based practices encouraged in most professional development workshops are applied instrumental acts intended to "fix" what is not working, reducing teaching and learning to predefined behaviors, finite goals, and pre-established rules and skills. And, the common reaction to what is being evidenced (ironically) is more quick "fixes". Thus, professional development becomes merely "what someone does to others" (Easton, 2008, 755) and fails to orient teachers to be purposefully involved as primary participants (Macintyre Latta \& Buck, 2007). Richardson (2003) terms such professional development as short-term transmission models, paying no attention to what is already going on in particular classrooms, schools, or school districts, offering little opportunity for participants to become involved in the conversation, and providing no follow-up (p. 401). Furthermore, little attention is paid to the agency of teachers and to the nature of how teachers learn based on their personal practical knowledge (Olson \& Craig, 2001). Critiquing evidenced-based practices in education, Biesta asserts this is "why what works, won't work". Teacher agency and authority are undermined as attention to the particulars of teaching/learning contexts are negated. Evidence-based practices are derived from causes and effects that are imposed no matter the context. For example, Sarah, a practicing teacher explains her lack of teaching agency encountering and implementing evidenced-based professional development fixes in this way: 
A disturbing professional climate of fear, insecurity, and watchfulness stirred by a new preoccupation with discussing "outcomes" became the norm. It seemed like every faculty meeting was driven by our mounting obligations to design, collect, analyze, and report student data which continues to grow, spilling into a second file drawer, unreviewed by the powers requesting its existence...inert data laying waste in a forgotten file cabinet drawer positioned to collapse from its own weight.

Sarah further relays her return to graduate studies in education as being a direct response to her growing anger, felt professional betrayal and disillusionment incapacitating her agentic roles within teaching and learning. A teacher's capacity to see and act accordingly within the act of teaching is the work of praxis. It seems that evidence-based practices driving many professional development initiatives are counterproductive to the work of praxis. They reify and totalize preconceived determinations of teaching and learning. Sarah's file drawers are filled with such student learning artifacts, but the relations across teacher, student, and subject matter that might have been evidenced are hidden, subsumed by the collective weight. We wonder how we can enable teachers like Sarah to gain professional agency, reinvigorating her teaching identity and her authority to foster student learning, thus claiming her praxis.

There is a growing body of research on educator professional development that provides guidelines for reform efforts (Darling-Hammond \& McLaughlin, 1995; Fullan \& Hargreaves, 1992; Jenlink \& Kinnucan-Welsch, 2001; Leiberman, 1996; Little, 1993; McCotter, 2001; Richardson, 2003). These guidelines emphasize that professional development should be experiential, empowering, ongoing, contextual, and collaborative, connecting theory and practice (McCotter, 2001). Further, recent research-based professional development studies suggest some common characteristics such as long-term initiatives with on-going follow-up, collegiality, 
supportive administration, access to adequate funding, and buy-in among participants (See Richardson, 2003). Attempts to reframe educator professional development are emerging, moving toward more constructivist orientations focusing on how teachers learn rather than what teachers learn (Easton, 2008; Jenlink \& Kinnucan-Welsch, 2001). These attempts focus on teacher learning while drawing across multiple research traditions and approaches. Our work, too, emphasizes teacher learning, but we pay attention to teacher professional learning that leads to praxis through narrative inquiry. We interrogate the possibilities of narrative inquiry in developing praxis for educators attempting to access the complexities of classrooms as productive for learners and learning.

\section{Narrative Inquiry as a Pedagogical Medium for Professional Development}

Narrative inquiry is a study of narrative that has become a field of its own focusing on its nature, its uses, and its significance (Bruner, 2002). It is a legitimate way of knowing and an act of sense making that shapes our conceptions and understandings about the world around us (Bruner, 1986, 1994). We draw the importance of narrative inquiry in professional development from Bruner's thinking and other educational philosophers such as Carr, Dewey, Ricoeur, Gadamer, and McIntyre whose work informs educational narrative researchers' views on the relations across narrative and experience (e.g., T Barone, 2001b; Clandinin \& Connelly, 2000; Connelly \& Clandinin, 1990; Polkinghorne, 1988, 1995; Verhesschen, 2003). Although these philosophers and narrative researchers may not share the same views on the relationships between narrative and experience (Verhesschen, 2003), they all acknowledge that narrative has a significant role in projecting lived experiences of people. Hence, there seems to be an organic relationship among narrative, experience and education as education is "a development within, by, and for experience" (Dewey, 1938, p. 28). Teaching and learning is a continuous process of 
reconstruction of experience (Dewey, 1938), which is expressed in narrative, revealing, representing, and transforming the organic relationship. Indeed, narrative gives shape to the lived experiences in education and often grants them a "title to reality" (Bruner, 2002, p. 8), which renders narrative inquiry a fitting form for studying and giving expression to educational experience.

Dunne (2003) also claims that research into teaching is best served by narrative modes of inquiry since "to understand a teacher's practice (on her own part or on the part of an observer) is to find an illuminating story (or stories) to tell of what she has been involved in with her students" (Dunne, 2003, p. 367). According to Dunne, teaching is an "enacted story" (p. 367) where teacher and students become characters contributing to and constructing a storyline, and actively seeking creative resolutions to tensions and conflicts that may occur in teaching and learning. In his later work, Dunne (2005) emphasizes the importance of stories that teacher and students live by, while drawing upon Aristotle who long ago suggested that story can instruct and move us precisely because they reveal universal themes in their depiction of particular cases and characters. MacIntyre (2002), in dialogue with Dunne, also expresses his view on 'narrative unity' as a catalyst that amalgamates the fragmenting tendencies of the story. He believes narrative unity can serve an important role in educational purposes. By becoming a good storyteller and a good listener to other people's stories, both teachers and students can see the lives of others and their own lives as a whole into which the fragmented parts of narratives can be integrated and embodied.

It is obvious that narrative is a medium through which we can understand ourselves and others (Ricoeur, 1991); through which our aspirations, vicissitudes, tensions, and conflicts are expressed (Bruner, 2002); and through which we make a selection of important elements of 
experience that need to be emphasized while discarding less important ones. Additionally, narrative is used to challenge our taken-for-granted ideas and to raise disturbing questions about educational issues, asking all involved to reconsider and reorient their thinking (Barone, 2001a, 2007). Then, narrative inquiry into teaching and learning has significant implications for classroom pedagogy, pedagogy for professional development in particular. It works as a pedagogical medium that invites teachers and students to look at their school experiences from multiple perspectives, helping each other interrogate their assumptions and taken-for-granted ideas and questioning the disabling contexts of teaching and learning. Hence, narrative inquiry becomes an engaging site for constructing praxis (Clark \& Medina, 2000), where particular kinds of wakefulness (Clandinin, Pushor, \& Orr, 2007) are required for educators to claim their praxis.

\section{Data Collection}

In the fall of 2007 and spring of 2008 we taught 3 curriculum courses at the graduate level in two different institutions, and these classes are used for data collection for our study. Each class had 8, 11, and 12 students respectively. For teachers who have little time to engage in their own reflective stories and reflective writing, and yet aspire to improve their practices, such graduate courses like ours become a major place for their professional development (See also Conle, 2001). It is a safe and open place where teachers can explore their fears, limits, boundaries, and potentials. Our curriculum theory classes become a search for fitting language, articulating the contextual terrain educators find themselves within and negotiating, given the specificity of teaching/learning situations. Participating educators write weekly narratives in graduate curriculum theory classes, inquiring narratively into the experiences of their teaching/learning practices, while facing questions about the content and form of their teaching and learning. Answering these questions through narrative inquiry requires thoughtful 
deliberations about what is worth knowing and experiencing. Even more fundamentally, such questions lead educators to query the essence of teaching and learning. The individual narratives of participating educators fold into the collective narratives, and then back into the individual narratives, in an ongoing purposeful movement, asking everyone to seize and explore possibilities for their personal teaching/learning practices. In our curriculum theory seminars, narrative inquiry becomes a medium for sharing and reframing critical incidents in classrooms. Connelly and Clandinin's (2006) temporal, social, and placial commonplaces of narrative inquiry become the relational ground that educators' narratives enter and navigate as the concrete realities of their classrooms increasingly draw their attention.

Data is collected through common expectations across both courses for all participants. These include:

1) Researcher field texts documenting the interchange across all participants and texts on an ongoing basis elucidating theory/practice relations throughout the duration of the course including weekly written responses to student narratives, instructor planning documents, and in-class discussion forums.

2) Educators' weekly narrative accounts of theory/practice relations through critical teaching/learning incidents, their planning documents, and associated artifacts.

3) The research literature situating the inquiry and the traditions inherited and being reconstructed.

As teacher educators we value teachers' narratives as they capture meaning and interpretation of teachers' lived experiences while providing a text to be examined and explored by and for teachers themselves. Narratives involve an intentional reflexive process of teachers interrogating their own teaching and learning (Lyons \& LaBoskey, 2002). Teachers' individual 
narrative accounts have metaphorical power as exemplary significances in particular settings capable of illuminating other settings (Dunne, 2005). It is our intention to illuminate and give expression to theory/practice relations through engagement with each other's narratives. As teachers call into question their practices they initiate their own personal curriculum theorizing alongside engagement with the research literature and alongside participants in graduate level curriculum theory seminars. Through incorporating weekly narrative accounts as an integral experience of the curriculum theory seminars, it is our hope that this translates into deeper understandings of learners and learning and teachers' agentic roles furthering their praxis.

\section{Data Analysis and Discussion}

The narratives position educators to examine the sense and teaching selves being revealed through reciprocal interaction and modification, inciting ways to proceed on an ongoing basis. Thus, reflexivity is at the heart of narrative inquiry. The weekly narrative accounts act as a catalyst for narrative unity (MacIntyre, 2002), figuring into collective thinking in each curriculum theory class, and returning to individual thinking, in a continuously reflexive discursive movement. As researchers we attend to the reflexive interchange created across all data sources, documenting the process, assessing the insights gained and the directions to proceed, on a regular basis. A reflexive approach (Alvesson \& Skoldberg, 2000) to data collection and analysis is considered essential, operating both inductively and deductively throughout, providing means to address the interface between the weekly narratives collected, the interpretations, and the research literature, situating the study and the traditions inherited and being reconstructed. The insights generated through reflexive analysis manifest just how critically important the narratives are as openings for educators to problematize their practices, as 
internalized connections to one's teaching identity, as invitations to live theory, enabling their praxis, and as interdependent within the social context acting as a catalyst for continued renewal.

As we examine the temporal, social, and placial relations present in the educators' reflective narratives across the weekly classes, increased cognizance of teaching and learning at the nexus of these intersections ensues. It is this nexus that forms the "undergoings" and "doings" (Dewey, 1934), the thinking within situations that teaching demands. The ongoing teacher discernment within this movement is the work of praxis. Educators' narratives attend to the undergoings and doings within their classrooms, making more visible the particulars of students, contexts, and subject matter. As they attend to the creation of learning deemed fitting for the given particularities, assuming and seeking relatedness and connectedness among teacher/student/subject matter, a productive space in-between what is given and what is to be achieved in classrooms, opens. Biesta (2004) terms this space the "gap" that is not to be avoided or urgently addressed, but rather, understood and mediated as the terrain of learning. The educators' narratives reveal a growing awareness of this in-between space as the necessary terrain of teaching and learning, asking all of us to attend to what we see and hear in each other's voices when asked to dwell mindfully at the intersections of teaching/learning situations. The temporal, social, and placial relations encountered in classrooms become modes of interaction. Such engagement makes it necessary to see the undergoings and doings of classrooms not as givens to be contemplated at a distance, but, rather, to see from within, "as something given and as something to be achieved conjointly" (Bakhtin, 1993, p. 30). The simultaneous awareness of both something given and something yet-to-be-achieved positions educators to realize that the concrete givens in classrooms are not simply steps toward something else, but rather, concomitantly a knowing of the present and how to meaningfully proceed. As educators' 
narratives invest in the relational workings of that in-between space of learning, common features emerge. These features position educators to dwell and build within the given complexities, embrace openness to the unexpected, and see the potentiality of the present within teaching/learning situations. These features characterize the development of a critical consciousness of praxis, awakened across participants. The critical consciousness gained through the interconnected perceiving, thinking, and feeling entailed, draws attention to the role and place of self-other negotiation. So, features mark the development of heightened consciousness of praxis by participating educators, eliciting ontological consequences that we find hold the pedagogical agency within praxis. The ontological consequences educators encounter and negotiate through the narrative features include other(s) as significant, other(s) enables selfunderstanding, and other(s) as transformative, thus, otherness awakens praxis. Attention now turns to these features and the ensuing ontological consequences, elucidating, deepening, and enlarging understandings of the productive potential within the in-between space for teaching and learning praxis. Our accounting of the features and ontological bearings of this agentic process unfolds as follows:

\section{Dwelling and Building Elicits the Significance of the Other}

The first feature is a capacity to $d w e l l$ and build within a complex space of differences assuming various experiential, philosophical, and pragmatic relations and orientations. Heidegger's (1977) essay "Building Dwelling Thinking” asks two questions: “1. What is it to dwell? 2. How does building belong to dwelling?" (p. 323). It is these questions that educators' narratives confront as they are asked to dwell within the relational complexities orienting any given teaching/learning situation as the necessary place to begin building learning relationships. Additional theorists that inform our weekly classes include Aoki (1992), Ayers (1988), Biesta 
(2004), Clark (1995), Dewey (1934; 1938), Pinar (2007), Sidorkin (2002), and Stengel (2004).

These readings call attention to the required teacher discernment disclosed through dwelling and investing in the relational complexities. Teachers are asked to reside amidst the complexity and seek ways to navigate the terrain encountered, for learning's sake. Representative narratives offer insights. For example, Lesa's thought dwells on the possibilities of the meaningful learning relationship, and wonders about the potential of building such a relationship:

If school is disengaging and lacks deliberate learning relationships but there is still evidence of some student achievement, then what might be the possibilities if we do engage them and develop meaningful learning relationships for learners and teachers?

The potential for growth is extraordinary. (Lesa's Narrative, Jan. 29, 2008)

The risks of dwelling and building in classrooms, as Lesa speculates, afford opportunities for understanding the relations with others. But to interpret and act on the opportunities, teacher watchfulness and thoughtfulness (Aoki, 1992) are integral to residing within the in-between space. Sara's narrative acknowledges how residing as such asks her to act and respond on an individual and moment by moment basis:

Today I felt very aware of the relations I am building with my students and who I think they each are (and are becoming). I think they are all in need of something from me and my job is to discover that need and do my best to fulfill it. For one it is a sense of knowing that someone cares, for another it is a challenge, for some it is security and for others being able to express frustrations. And, these are always changing. I need to be in touch with students and their learning. (Sara's Narrative, March 21, 2008) 
Dwelling and building also calls teaching/learning practices into question. Brooke's narrative confronts the "contorted" teaching identity she assumes daily and Leyla's narrative confronts multiple contradictions present in classrooms.

I feel manipulated as I contort to the demands set for me to achieve with my students, pulled and stretched in so many directions that finding learning purpose is totally lost for me, never mind my students. (Brooke's Narrative, March 11, 2008)

Contradictions explode and implode as I think about teaching and learning. Students packed tightly into classrooms yet interaction is restrained with silence and aloneness valued. Students asked to work in harmony but strangers to each other. Students encouraged to help each other but to avoid looking at each other's work. Students urged to be independent and critical thinkers but required to be obedient to the teacher. Students asked to cooperate yet in competition with one another. Students required to work carefully and thoroughly but constantly reminded of the shortness of time to do so. (Leyla’s Narrative, Feb. 14, 2008)

And, Jennifer relays the personal investment in her students demanded by dwelling and building in classrooms:

At the end of a school year it is often painful to say goodbye to students I have come to know, appreciating their differences, and gaining insights from each one. But, I would not want it otherwise. My own children are about to enter the school system and I desperately want them to experience learning as deeply connected to them. (Jennifer's Narrative, Jan. 29. 2008) 
Dwelling and building within the given relationalities of classrooms acknowledges the complexities of otherness that learners bring to all learning situations. The more educators reside within such a space, the more they discern the complexities at play within teaching/learning situations. Educators' narratives convey concomitantly fear and humility as they discern more and more. It becomes important to affirm such fear and humility as mustering the boldness required to reside in classrooms in discerning ways. Educators articulate the significance of other(s) arising out of greater discernment. The narratives grapple with what is to be gained by attending to other(s), teachers and students co-creating meaning within the space created inbetween. This self-other space assumes open, vulnerable, questioning beings. The receptive nature of active engagement becomes clear. Educator's attention on self as teacher is decentered. The narratives foster collective discussions about how meaningful teaching and learning could not take place if teachers are the central figure. The uniqueness that others and otherness bring is valued as catalytic and connected to sense making of all kinds. Both Stephanie's and Brooke's narrative excerpts offer representative examples of how interdependency across self and other is increasingly discerned as productive for teaching and learning connections.

If only my students knew how irritated I was, how preoccupied I was, how difficult it was to get here this morning, how excited I am that they all showed up on time...if they only knew me. Somewhere I internalized the idea that teachers must act like they are in control of everything; never let on that I might be surprised by something or someone; think on my feet and always expect the unexpected — but do not let them in on the fact that it was unexpected. A façade of competence and authority took over and I felt in control as a teacher but completely lost as to whom I was. I thought the control, organization, and 
repetition would see me through to better times, to times with inspiration and excitement in my teaching career. But now as I look with wider more discerning eyes, I admit I am not the teacher I want to be. It should not be me as teacher against my students. Are we not all here to learn with and from each other? (Stephanie's Narrative, Feb. 26, 2008)

As a beginning teacher I understood that teaching was about setting goals and following given information and techniques to reach learning goals with students. I knew teaching to be presenting information through activities, lectures, and other media. But, as I have experienced teaching I never found it to be this tidy. Not only are students transformed by what they learn, but, I am transformed by what I teach and through the interactions on a daily basis we all change. Through baptism though fire, I have come to understand teaching has to do with judgment more than skill. It is the relational judgments that I make within teaching moments that confirm to me that I am teaching. (Brooke's Narrative, March 11, 2008)

The narrative interchange that is generated across participating educators reiterates Heidegger's (1977) premise that building prospers because of dwelling thinking, eliciting the significance of the other. Understanding the importance of dwelling and building meaningful teaching/learning connections through other(s) surfaces, and opportunities for fostering critical consciousness of praxis ensue.

\section{Openness Assumes Self-Understandings in Need of the Other}

The second feature is the capacity to comprehend that there is always more to be seen and understood. The narratives increasingly embrace this kind of openness as a necessary quality. Gadamer (1964) claims openness is critical to becoming experienced in all undertakings. And, 
though most educators might admit comprehending this feature, the narratives disclose the concrete consequences of doing so within teaching and learning. As educators acknowledge and work with the complexities of given classrooms, they become conscious of how the content of their lessons can take various shapes and directions in unexpected ways. Theorists that we turn to for language and insights include Ayers (1993), Barone (2000), Block (2001), Carr (2000), Cochran-Smith (2001), Dewey (1934), Flinders and Thornton (2004), Gallego, Hollingsworth and Whitenack (2001), Paley (1986), Palmer (1998), Pinar (2007), Thayer-Bacon (2004), and Van Manen (1991). Each theorist draws attention to potential aspects of the relational interplay shaped through classroom interaction, deliberation, and dialogue, positioning teachers and students to make meaning derived largely from what surfaces throughout process. Openness to unasked for and unpredictable learnings, with change and transformation possible, must be assumed. The meanings negotiated are understood as tentative, representing moments of clarity, but also holding unfinished or incomplete thinking that persists. Narratives characterize openness as a ceaseless search for learning connectiveness. Lesa, Annette, and Becky explain:

To grow into the role of a teacher who empowers students by careful listening and guided exploration takes time. It requires patience. Wanting to give answers and move on is practically an instinct in the classroom and fighting that urge is like holding back a locomotive. Taking time to derail the train, unpacking meaning and relevance with students (not for them) entails positioning students to find learning connections and these finds are not always found at the same time and need to be found again and again. (Lesa's Narrative, Feb. 26, 2008) 
I am seeing more and more within each moment in my classroom. It can be overwhelming if you think about it too long. But, I am catching myself as I teach and really trying to listen to my students. I am listening through their spoken words but also through their expressions and body language, their assignments, and the closer I listen I find myself teaching in unexpected ways. The other day after carefully planning out a lesson and mapping out the unit with my teaching team, I found myself abandoning the scripted direction and following through with students' wonderings about texture in an art lesson with my grade 3 students. (Annette's Narrative, Nov. 12, 2007)

I like the idea of teaching as a living thing. I have been using a journal assignment with my students to help me understand their viewpoints and respond personally to each one. I have felt an energy and enthusiasm released in students and myself. Lately, though, with district pressures to record and document specific learning goals and their achievement, I have let the journals become less about personal student learning and more about my accountability to the predetermined goal statements. I am going to rectify this. (Becky's Narrative, Oct, 30,2007)

Through openness to unexpectedness and wonderings of students, Lesa, Annette, and Becky try to find themselves in their teaching praxis. They offer representative versions of the narratives shared and discussed on a weekly basis resisting the confines of understanding being private, autonomous, and calcified. Rather, self-understandings of one's teaching identity are thus embedded in the social and public, disclosed in the communal negotiation of meaning making in need of other(s). Stephanie states: 
I am adjusting my expectations to be more open and flexible alongside identifying myself within the experience and engaging in it with my students. (Stephanie's Narrative, Feb. $26,2008)$

And, similarly Patti characterizes the communal negotiation of meaning as an invitation deserving of everyone's respect:

Teachers and students are invited into each other's lives. The invitation and the learning process deserve our collective and personal respect. It is humbling to witness moments when students recognize personal connections to curriculum and realize the power of learning with and through others. (Patti's Narrative, Jan. 29, 2008)

Educators are invited to make sense of the world through engagement with other(s). This commitment to engagement with the other respects the uniqueness as well as the familiar and shared qualities that resonate across all. It acknowledges that we enter into relationships as historical beings and assumes a desire to be challenged. Educators' narratives encounter differences of all kinds in classrooms asking them to continually confront and consider who they are, and who they are becoming, as teachers. Encountering the other within the collective sharing of these narratives fosters self-understandings always in process. Educators discover how understandings and otherness are intrinsically linked within the unfolding of the self. Gadamer (1964) delineates how understanding conceived as such always implies a pre-understanding, prefigured by the tradition in which the interpreter lives and which shapes his/her prejudices. Every encounter with otherness therefore embraces openness with the "suspension" of one's own prejudices, investing in the meaning making of others as productive opportunities to enlarge and challenge one's understandings. 


\section{Seeing Potentiality within the Present Transforms Self and Other}

The third feature acknowledges the dynamic nature of knowing. Educators' past sensemaking figures into present teaching/learning situations with potential for future study. As educators share their personal narratives and attend to the narratives of others, an individual and collective movement of thinking takes shape. The dynamic nature of knowing emerges as educators participate in the "reorganizing or reconstruction of experience" (Dewey, 1934, p. 76). Teacher narratives embody the unique, personal, humanness of meaning making with knowledge generated through self-experience with other(s). Greene (1988) characterizes such movement as a dialectic of freedom in which "one's reality rather than being fixed and predefined is a perpetual emergent, becoming increasingly multiplex, as more perspectives are taken, more texts are opened, more friendships are made" (p, 23). Additional theorists such as Buber (1923/1958), Carr (2000), He, Phillion, Chan, and Xu (2007), Liston (2004), and Nieto, Bode, Kang, and Raible (2007), ask us to examine how the dynamic nature of knowing must be attended to from within the search for meaning. Narratives relay educators grappling with the relational immediacy of this negotiation. For example, Rob explains his attempts to attend to the dynamic movement of student thinking in his classroom as follows:

In my classroom the best teaching moments felt like good conversations, but tests felt like rude interruptions. All good conversations involve a loss of self-consciousness, what Buber calls moving from an "I-It" relationship to an "I-Thou" relationship. The best and most educative experiences in the classroom resulted from this kind of immersion in meaning making, genuine "I-Thou" conversations. I might have introduced a topic or question, but students talked about the idea, transforming it into a real conversation that drew us all in. I would eventually realize that I needed to somehow grade student 
knowledge of the topics and I would assign some task and grade it accordingly. This evaluation would feel very out of place in a real conversation. A conversation partner does not leap back from an engaging discussion to grade their partner's effective use of terminology, or interrupt the conversation to administer a pop quiz on their partner's skills. (Rob's Narrative, Feb. 26, 2008)

Rob grapples with valuing the relational immediacy of learning and with ways to document the transformative thinking he sees and feels in his classroom. Similarly, Leyla insists that valuing the dynamic movement of learning looks to the present in order to see concomitantly the past and into the future:

I believe that a goal of a teacher is to discover who her students are TODAY. And discover it over and over again every day in the context of the present day. (Leyla's Narrative, Feb. 24, 2008)

Relations, as Rob and Leyla point out, are negotiated again and again through encounters with otherness. The dynamic movement of learning fosters renewed senses of student and teacher identities, changing and growing as relations are encountered and engaged. Teaching and learning are infused with life and novelty. The ongoing search, locating self within this movement, is the transformative work of understanding. Transformation acknowledges the reciprocity of active engagement with everyone/thing changing in the process (Gadamer,1964). It is such reflexive engagement that the narratives relay to be generative; productive for building teaching and learning connectiveness. For example Rob states:

Teachers who keep themselves at a distance from their subject matter also create distance within their students. We ask our students to integrate what we teach somehow into their worlds and students need to see teachers transforming "subject" into "identity", changing 
"that" into "me"... Reflecting on the importance of these moments could lead me to understand the contexts that make them possible. I might be able to better support (and inspire) these moments of transformation for students and myself. (Rob's Narrative, Feb.

24, 2008)

And, as Leyla's earlier comment states and Rob alludes to above, transformation insists on seeking potential within the present. Educators' narratives increasingly document meaning as something always to be achieved, striving for unrealized potential. Educators' narratives also relay how these learning situations involve "those who think and know how to think participatively" (Bakhtin, 1993, p. 19). Participatory thinking demands receptivity to sensory qualities and relations within learning situations, inciting inquiry. Theorists such as Caputo (1987), Day (2004), Dewey (2004), Hansen (2001), and Kemmis and Smith (2008) further our thinking regarding building meaning interdependent with seeing situations as sites of action, with an obligation to the future, to generativity, to the possible, thus, always in immediate relationship to the particulars of given teaching/learning contexts. Trisha's Narrative depicts such engagement as follows:

When taking the ability away for teachers to plan for their own students, we begin to circumvent the ability to listen, think, speak, attend, and judge what is happening in our classrooms. One way I create space to purposefully engage accordingly is during read alouds. Currently, I am reading the book Freedom Walkers, which is about the Montgomery Bus Boycott. It has created a time for my class to discuss discrimination, bullies, and passive resistance. Today a student came up to me and said, "If they only made $\$ 5$ a week, why didn't they go for more money instead of just the bus?” Thus began a brief discussion as to the need to begin somewhere and better seating was probably a 
simpler issue than better pay at the time. Then I gave him the book to continue reading aloud. Today this young man, who has several mental health issues controlled by medications, did not take his meds until very late in the day, was beginning to struggle but was able to read for over 30 minutes. No, I did not plan for this conversation. I did listen. I did judge that he was going to struggle with listening for the latter part of the day. I did find a way to broaden and deepen this student's knowledge and understandings. And, it provided a wonderfully full teaching moment for all. (Trisha's Narrative, March $21,2008)$

Trisha's narrative powerfully conveys how otherness awakens identities. What is unique and particular in this teaching/learning situation matters and is evoked. Through conversing, a shared responsibility is entered into. It is such commitment to engagement with the other that guides where the participating educators' individual/collective conversation has been and is going. The narrative movement conceives otherness as an operating construct for praxis. As such, otherness translates into a pedagogical movement entrusted with the growth and wellbeing of other(s). Narratives manifest the creating, responding, and relating teaching/learning movement of thinking with other(s), thus, indifference to what is unique and particular is more difficult to ignore. Narratives talk of respecting the ethical space such a movement of thinking enters. Narratives share an awe regarding what the present holds for the future; for the next moment of a lesson; for the potential seen in other(s), in the short and long term.

The three features fold into each other and the narratives recursively and continuously illuminate the in-between space of what the particular givens within the contexts of specific classrooms offer and what might be achieved. Such cognizance of teacher narratives encounters otherness to be productive, presenting opportunities to build selves and understandings in 
relation to it. The narrative movement as a whole, across participating classes, elicits the other, calling our very selves into question. Educators engaged in narrative inquiry see what is at stake within specific teaching/learning situations, inciting a turn and re-turn to self-understandings, acting on possibilities again and again in an "ever-present process" (Dewey, 1938, p. 50), manifesting as a backward movement that re-covers and re-presents, alongside a forward movement that generates and evokes. Within this recursive movement, the narratives become a medium to seek out and seize back possibilities for teaching/learning praxis. It fosters professional identities that are in touch with self as teacher, self as individual, students, and given learning contexts. Educators find and negotiate greater agency for student learning through such connectedness. It is an agency informed by the primary relation of building to dwelling at the core of praxis. And, to access and gain such agency, the role and place of the other(s) seems vital.

\section{Claiming the Creative Space of Praxis: The Formative Work of Professional Development}

Educators' narratives move from conveying their teaching identity and roles as being more concerned with problem fixing toward insisting on the other(s), and, thus, on contingency. The teacher narratives reflect that educators attend regularly to the undergoings and doings of their classrooms creating room to dwell and build a Deweyan (1934) confidence in process, apprehending and articulating the significances of doing so, for teachers and for learners. The individual and collective nature of this sense-making embraces the process itself. And, it is within the formative process that educators locate the significances and translate these into ongoing attempts to claim the agency at the core of praxis. Translation entails room to navigate theory/practice relations, forming, enlarging, and deepening understandings, and thus building the confidence and commitment afforded by teacher agency for student learning. This study 
reveals how narrative inquiry creates such room. The features and consequences encountered of dwelling and building eliciting the significance of the other, openness assuming selfunderstandings in need of the other, and seeing potentiality within the present transforming self and other, trace the formative translations in the making, accessed by educators through narrative inquiry. Such access prompts greater individual and collective cognizance of educator's praxis. In doing so, meaningful professional development for teacher learning and growth is revealed in our study as necessitating educator nearness to the particulars of teaching and learning as the translating ground for professional development, forming and re-forming embodied understandings, creating space for negotiating understandings, and finding language to articulate understandings with/to others.

The translation of praxis requires nearness. Educators need time to account for the concrete relational undergoings and doings of their classrooms. These accountings, alongside the accountings of others, bring educators near to the particulars of their students, contexts, and learning relations. The specificities and vivid tales alive in the narratives clarify that these are not cause and effect understandings of relation, but rather, about "generation, influence, and mutual modification" (Dewey, 1934, p. 134). This distinction reorients teaching from the "cause" of learning to the "context" for learning (Biesta, 2007; Green \& Reid, 2008). Through such "hold upon nearness" (Gadamer, in Misgeld \& Nicholson, 1992, p. 257) a familiarity is gained that is difficult to disregard and orients educators' praxis toward context. The narrative interchange creates nearness to the undergoings and doings of classrooms, problematizing teaching and learning for educators, suggesting informed professional action attending to means and ends in education as being internally rather than externally related (Biesta, 2007, p. 10). 
The translation of praxis requires embodied understandings. The narratives depict a felt relationship across undergoings and doings of classrooms experienced at moments in educators' teaching practices. As educators dwell and build relationships among self, others, and subject matter, the narratives avail opportunities for educators to live in-between these entities, where "past possibilities of action become future possibilities that are repeated in the moment of decision" (Risser, 1997, p. 38). Dewey (1934) terms this a "double change" converting an "action into an act of expression" (p. 60). Dewey further explains that such mindfulness relies on all the senses to inform actions. And, he insists that neither action nor intellect can be separated from these found qualities. In doing so, he characterizes the mind as a verb. It is this double change that the narratives negotiate and enable, with educators experiencing the movement of their own thinking and concomitantly grappling with their attempts to move the minds of their students. "Moving minds" demands embodied praxis (Bresler, 2004). The narratives generate embodied understandings of praxis through inviting educators to theorize their practices, living theory within the concrete realities of their daily teaching/learning practices.

The translation of praxis also requires affirmation, courage, and negotiating room. Seeking theory/practice conjunctures asks educators to inhere in the sensible, reorienting teaching and learning toward meaning making. The complexities and difficulties that form and re-form the individual and collective narrative interchange become the shared ground of the work of learning, catalytic for their praxis. Educators affirm each other's experiences, encourage and challenge each other to pursue ways to attend to the undergoings and doings of classrooms, and document the significances for learners and learning. The more they invest in this shared ground, the more confidence and courage to create space for praxis is realized, enabling individual and collective efforts. 
Finally, the translation of praxis requires language to articulate with/to others. The theory engaged throughout the curriculum seminars gives voice to the undergoings and doings of classrooms. But, it is educators' theorizing attempts to allow both theory and practice to better inform, that is shape from within the teaching/learning situation what teachers do in classrooms, that instills a language of praxis. Locating such conjunctures entails building relationships between self, others, and subject matter. This study reveals that this intertwining relationship becomes visible and tangible through the narrative interchange disclosing this conjuncture as a "sensible thing" (Merleau-Ponty, 1964) cohering a sense of unity into their teaching practices and teaching identities. Over time and with lived commitment, language is increasingly accessed through the intertwining of the individual/collective movement of thinking, fostering teacher agency for student learning. The narrative discourse generates stronger internalized teaching identities with a collective sense of purpose.

Based on our findings, we argue that professional development that engages narrative inquiry invites educators to claim the creative space of praxis. In doing so, the formative work of professional development takes shape and life. Teacher narratives in our study reveal a narrative interchange with common features and ontological consequences that characterizes the development of a critical consciousness of praxis across all participants: dwelling and building elicits the significance of the other; openness assumes self-understandings in need of the other; and seeing potentiality within the present transforms self and other. Hence, professional development that utilizes narrative inquiry as a medium should provide translating space, time, and supports for teachers to get near to the undergoings and doings of classrooms, develop embodied understandings through negotiating theory practice relations, and access lived language through the individual/collective narrative interchange. Positioning educators to have 
ongoing contact and communication with the particulars of their classrooms and putting them in ongoing dialogue with each other causes educators to concretely experience the significances for learners and learning for themselves. Teaching and learning becomes animated for educators and we saw hope that such animation was increasingly sought within individual classrooms and with their students. Educators' narratives indicate that when such nearness of contact and communication is lost, thinking becomes unnecessary. At an extreme, it is reduced to a mechanical response. Educators describing creating, adapting, and discerning teaching/learning circumstances take advantage of new opportunities to learn, modify situations to make them more compatible with their own teaching contexts while drawing upon available resources, and invent their own practices to solve novel problems rather than mindlessly applying quick "fixes" (Bransford \& Schwartz, 1999). The collective opportunities to relay these experiences undergo “constant movement and extension" (Gadamer, 1975/2006, p. 298). The narratives became the intermediary, a medium extending "an invitation to see the world differently...to act in a different way" (Verhesschen, 2003, p.454). The research literature conveys that over and over again the impact of teachers on the quality of education is vastly underestimated and undermined. The narrative interchange this study documents directly challenges this, involving professional learning opportunities purposefully interdependent with others. "Professional learning so constructed is rooted in the human need to feel a sense of belonging and of making a contribution to a community where experience and knowledge function as part of community property" (Lieberman \& Pointer-Mace, 2008, p, 227). Educators need to claim this space as the creative work of teaching and learning. They need to know these qualities and practice creating with them as the needed responsive agency within teaching and learning. Dewey (1934) sees agency as central to human flourishing. The creative space of classrooms assumes that to be fully 
human is to be alive, embracing thinking and feeling, seeing and acting. The narrative interchange created across educators invites such vitality, modeling the responsive educator agency all involved in this study are so desperately seeking. 


\section{References}

Alvesson, M., \& Skoldberg, K. (2000). Reflexive methodology. London: Sage.

Aoki, T. (1992). Layered voiced of teaching: The uncannily correct and the elusively true. In W. F. Pinar \& W. M. Reynolds (Eds.), Understanding curriculum as phenomenological and deconstructed text (pp. 25-26). New York: Teachers College Press.

Ayers, W. (1988). Thinking about curriculum. Harvard Educational Review, 56(1), 49-51.

Ayers, W. (1993). To teach. New York, NY: Teachers College Press.

Bakhtin, M. M. (1993). Toward a philosophy of the act. Austin, TX: University of Texas Press.

Barone, T. (2000). Aesthetics, politics, and educational inquiry: essays and examples. New York: Peter Lang Publishing.

Barone, T. (2001a). Pragmatizing the imaginary: A response to a fictionalized case study of teaching. Havard Educational Review, 71(4), 735-742.

Barone, T. (2001b). Touching Eternity: The enduring outcomes of teaching New York: Teachers College Press.

Barone, T. (2007). A return to the gold standard?: Questioning the future of narrative construction as educational research. Qualitative Inquiry, 13(4), 454-470.

Barton, P. (2006). Needed: Higher standards for accountability. Educational Leadership, 64, 2831.

Biesta, G. (2004). Mind the gap! In C. Bingham \& A. Sidorkin (Eds.), No education without relation (pp. 11-22). New York: Peter Lang.

Biesta, G. (2007). Why 'what works' won't work: Evidencee-based practice and the democratic deficit of educational research. Educational Theory, 57(1), 1-22.

Block, A. (2001). I'm only bleeding. New York, NY: Peter Lang. 
Bransford, J., \& Schwartz, D. L. (1999). Rethinking transfer: A simple proposal with multiple implications. In A. Iran-Nejad \& P. D. Pearson (Eds.), Review of research in education (pp. 61-100). Washington, DC: American Educational Research Association.

Bresler, L. (Ed.). (2004). Knowing bodies, moving minds: Towards embodied teaching and learning. Boston: Kluwer Academic Publishers.

Bruner, J. (1986). Actual minds, possible worlds. Cambridge, MA: Harvard University Press.

Bruner, J. (1994). Life as narrative. In A. H. Dyson \& C. Genishi (Eds.), The need for story: Cultural diversity in classrom and community (pp. 28-37). Urbana, IL: National Council of Teachers of English.

Bruner, J. (2002). Making stories: Law, literature, life. New York: Farrar, Straus and Giroux. Buber, M. (1923/1958). I and Thou (R. G. Smith, Trans.). New York: Charles Scribner's Sons.

Caputo, J. D. (1987). Radical hermeneutics: Repetition, deconstruction and the hermeneutic project. Bloomington: Indiana University Press.

Carr, D. (2000). Professionalism and ethics in teaching. London: Routledge.

Clandinin, D. J., \& Connelly, M. (2000). Narrative inquiry: experience and story in qualitative research San Francisco: Jossey-Bass.

Clandinin, D. J., Pushor, D., \& Orr, A. M. (2007). Navigating sites for narrative inquiry. Journal of Teacher Education, 58(1), 21-35.

Clark, C. (1995). Thoughtful teaching. New York, NY: Teachers College Press.

Clark, C., \& Medina, C. (2000). How reading and writing literacy narratives affect preservice teachers' understandings of literacy, pedagogy, and multiculturalism. Journal of Teacher Education, 51(1), 63-76.

Cochran-Smith, M. (2001). Constructing outcomes in teacher education: Policy, practice and 
pitfalls. Education Policy Analysis Archives, 9(11), 1-57.

Cochran-Smith, M., \& Lytle, S. L. (2001). Beyond certainty: Taking an inquiry stance on practice. In A. Lieberman \& J. L. Miller (Eds.), Teachers caught in the action: Professional development that matters. New York: Teachers College Press.

Conle, C. (2001). The rationality of narrative inquiry in research and professional practice. European Journal of Teacher Education, 24(1), 21-33.

Connelly, F. M., \& Clandinin, D. J. (1990). Stories of experience and narrative inquiry. Educational Researcher, 19(4), 2-14.

Connelly, F. M., \& Clandinin, D. J. (2006). Narrative inquiry. In J. L. Green, G. Camilli \& P. Elmore (Eds.), Handbook of complementary methods in education research (3 ed., pp. 477-487). Mahwah, NJ: Lawrence Erlbaum.

Darling-Hammond, L. (1996). What matters most: A competent teacher for every child. Phi Delta Kappan, 76(8), 597-604.

Darling-Hammond, L., \& McLaughlin, M. W. (1995). Policies that support professional development in an era of school reform. Phi Delta Kappan, 76(8), 597-604.

Day, C. (2000). Stories of change and professional development: The costs of commitment. In C. Day, A. Fernandez, T. Hauge \& J. Moller (Eds.), The life and work of teachers: International perspectives in changing times (pp. 109-129). London: Falmer Press.

Day, C. (2004). A passion for teaching. London: RoutledgeFalmer.

Delpit, L. (2000). The silenced dialogue: Power and pedagogy in the education of other peoples' children. Harvard Educational Review, 58(3), 280-298.

Dewey, J. (1934). Art as experience. New York: Capricorn Books.

Dewey, J. (1938). Experience and Education. New York: Macmillan. 
Dewey, J. (2004). My pedagogic creed. In D. J. Flinders \& S. J. Thornton (Eds.), The curriculum studies reader (pp. 17-23). New York, NY: Routledge.

Dunne, J. (2003). Arguing for teaching as a practice: a reply to Alasdair MacIntyre. Journal of Philosophy of Education, 37(2), 353-369.

Dunne, J. (2005). An intricate fabric: understanding the rationality of practice. Pedagogy, Culture and Society, 13(3), 367-389.

Easton, L. B. (2008). From professional development to professional learning. Phi Delta Kappan, 89(10), 755-759.

Flinders, D. J., \& Thornton, S. J. (Eds.). (2004). The curriculum studies reader. New York, NY: Routledge.

Fullan, M. G. (1999). Change forces: The sequel. London: Falmer Press.

Fullan, M. G., \& Hargreaves, A. (1992). Teacher development and educational change. London: Falmer.

Gadamer, H. (1992). Truth and method. New York: Continuum.

Gadamer, H. G. (1964). Truth and method. New York: Continuum.

Gadamer, H. G. (1975/2006). Truth and method (2 ed.). New York, NY: Continuum.

Gallego, M. A., Hollingsworth, S., \& Whitenack, D. A. (2001). Relational knowing in the reform of educational cultures. Teachers College Record, 2(April), 240-266.

Green, B., \& Reid, J. (2008). Method(s) in our madness? In A. Phelan \& J. Sumsion (Eds.), Critical readings in teacher education (pp. 17-31). Rotterdam: Sense Publishers.

Greene, M. (1988). The dialectic of freedom. New York, NY: Teachers College Press.

Hansen, D. T. (2001). The moral heart of teaching: Toward a teacher's creed. New York: Teachers College Press. 
Hargreaves, A. (2002). Teaching in a box: Emotional geographies of teaching. In C. Sugrue \& C. Day (Eds.), Developing teachers and teaching practice: International research perspectives (pp. 3-25). London: RoutledgeFalmer.

He, M. F., Phillion, J., Chan, E., \& Xu, S. (2007). Immigrant students' experience of curriculum. In F. M. Connelly, M. F. He \& J. Phillion (Eds.), Handbook of curriculum and instruction. Thousand Oaks, CA: Sage Publications.

Heidegger, M. (1977). Basic writings. New York: Harper Row.

Ingersoll, R. M. (2002). The teacher shortage: A case of wrong diagnosis and wrong prescription. NASSP Bulletin, 86(631), 16-30.

Jenlink, P. M., \& Kinnucan-Welsch, K. (2001). Case stories of facilitating professional development. Teaching and Teacher Education, 17(6), 705-724.

Kemmis, S., \& Smith, T. (2008). Praxis and praxis development. In S. Kemmis \& S. T. (Eds.), Enabling praxis: Challenges for education (pp. 3-14). Rotterdam, The Netherlands: Sense Publishers.

Kincheloe, J., Slattery, P., \& Steinberg, S. (2000). Contextualizing teaching: Introduction to education and educational foundations. Reading, Mass.: Longman.

Lieberman, A. (1996). Practices that support teacher development: Transforming conceptions of professional learning. In M. W. McLaughlin \& I. Oberman (Eds.), Teacher learning: New policies, new practices (pp. 185-201). New York: Teachers College Press.

Lieberman, A., \& Pointer-Mace, D. H. (2008). Teacher learning: The key to educational reform. Journal of Teacher Education, 59(3), 226-234.

Liston, D. P. (2004). The lure of learning in teaching. Teachers College Record, 106(3), 459486. 
Little, J. W. (1993). Teachers' professional development in a climate of educational reform. Educational Evaluation and Policy Analysis, 15(2), 129-151.

Lyons, N., \& LaBoskey, V. K. (2002). Why narrative inquiry or exemplars for a scholarship of teaching? In N. Lyons \& V. K. LaBoskey (Eds.), Narrative inquiry in practice: advancing the knowledge of teaching (pp. 11-30). New York: Teachers College Press.

MacIntyre, A., \& Dunne, J. (2002). Alasdair MacIntyre on education: In dialogue with Joseph Dunne. Journal of Philosophy of Education, 36(1), 1-19.

Macintyre Latta, M., \& Buck, G. (2007). Professional development risks and opportunities embodied within self-study. Studying Teacher Education, 3(2), 189-205.

McCotter, S. (2001). Collaborative groups as professional development. Teaching and Teacher Education, 17(6), 685-704.

Merleau-Ponty, M. (1964). Signs. Evanston: Northwestern University Press.

Misgeld, D., \& Nicholson, G. (Eds.). (1992). Hans Georg Gadamer on education, poetry, and history: Applied hermeneutics. Albany, NY: SUNY Press.

Neito, S., Bode, P., Kang, E., \& Raible, J. (2007). Identity, community, and diversity: Retheorizing multicultural curriculum for the postmodern era. In F. M. Connelly, M. F. He \& J. Phillion (Eds.), Handbook of curriculum and instruction. Thousand Oaks, CA: Sage Publications.

Nias, J. (1996). Thinking about feeling: The emotions in teaching. Journal of Education, 26(3), 293-306.

Noddings, N. (1996). Stories and affect in teacher education. Journal of Education, 26(3), 435447.

Olson, M. R., \& Craig, C. (2001). Opportunities and challenges in the development of teachers' 
knowledge: The development of narrative authority through knowledge commmunities. Teaching and Teacher Education, 17(6), 667-684.

Paley, V. G. (1986). On listening to what the children say. Harvard Educational Review, 56(2), $122-131$.

Palmer, P. J. (1998). The courage to teach: Exploring the inner landscape of a teacher's life. San Francisco, CA: Jossey-Bass.

Pinar, W. F. (2007). Intellectual advancement through disciplinarity: Verticality and horizontality in curriculum studies. Rotterdam and Taipei: Sense Publishers.

Polkinghorne, D. E. (1988). Narrative knowing and the human sciences. Albany, New York: State University of New York Press.

Polkinghorne, D. E. (1995). Narrative configuration as qualitative analysis. In J. A. Hatch \& R. Wisniewski (Eds.), Life history and narrative (pp. 5-25). London: Falmer Press.

Richardson, V. (2003). The dilemmas of professional development. Phi Delta Kappan, 84(5), 401-409.

Ricoeur, P. (1991). From text to action: Essays on hermeneutics. Evanston: Northwestern University Press.

Risser, J. (1997). Hermeneutics and the voice of the other: Re-reading Gadamer's philosophica hermeneutics. New York: State University of New York Press.

Schön, D. A. (1983). The reflective practitioner: How professionals think in action: Basic Book, Inc.

Sidorkin, A. (2002). Learning relations: Impure education, deschooled schools, \& dialogue with evil. New York: Peter Lang.

Stengel, B. (2004). Knowing is response-able relation In C. Bingham \& A. Sidorkin (Eds.), No 
education without relation (pp. 139-152). New York: Peter Lang.

Thayer-Bacon, B. J. (2004). Personal and social relations in education. In C. Bingham \& A. Sidorkin (Eds.), No education without relation (pp. 165-179). New York: Peter Lang.

Trachtman, R. (2007). Inquiry and accountability in professional development schools. Journal of Educational Research, 100(4), 197-203.

U. S. Department of Education (2002). The No Child Left Behind Act. Washington, D. C.

Van Manen, M. (1991). The tact of teaching. London, Ontario: Althouse Press.

Verhesschen, P. (2003). 'The poem's invitation': Ricoeur's concept of mimesis and its consequences for narrative educational research. Journal of Philosophy of Education, 37(3), 449-465.

NI invites Professional Development 38 